\title{
BULLETIN of The BUSINESS HISTORICAL SOCIETY
}

INCORPORATED

BAKER LIBRARY, SOLDIERS FIELD, BOSTON 63, MASS.

Henrietta M. Larson, Editor

Vol. XIX,No.4 October, 1945 Whole No.115

\section{Shifts in Public Relations}

\author{
By N. S. B. Gras
}

1. What are public relations?

2. Rise of an interest in public relations

3. Business is business : a fundamental dictum 102

4. Let business alone, relatively speaking

5. The first period in the history of public relations: the public must help business

6. The second period in the history of public relations : let the public keep its hands off business and let business men freely compete

7. The third period in the history of public relations: economic freedom is dangerous; regulation and control are the only enduring systems

8. The public be pleased (but fooled)

9. The public be fully served and fully informed (and perhaps partly educated)

10. Public relations counsellors

11. Public relations departments

12. Effect of business changes, especially depressions, on public relations

13. Other business factors in the creation of bad public relations

14. Success, failure, and difficulties in public relations 